\title{
Identifikasi Tumbuhan Paku (Pteridophyta) di Universitas Islam Negeri (UIN) Sumatera Utara
}

\section{Identification of Ferns (Pteridophyta) in Universitas Islam Negeri (UIN) Sumatera Utara}

\author{
Miza Nina Adlini ${ }^{1}$, Adi Hartono ${ }^{1}$, Miftahul Khairani ${ }^{1}$, Indayana Febriani Tanjung ${ }^{1}$, \\ Khairuna $^{1}$ \\ ${ }^{\text {I} P r o g r a m ~ S t u d i ~ T a d r i s ~ B i o l o g i, ~ F a k u l t a s ~ I l m u ~ T a r b i y a h ~ d a n ~ K e g u r u a n, ~ U n i v e r s i t a s ~ I s l a m ~ N e g e r i ~ S u m a t e r a ~}$ \\ Utara \\ Jalan Williem Iskandar Pasar V Medan Estate 20371, Sumatera Utara, Indonesia \\ Email: adi.hartono@uinsu.ac.id *Penulis Korespondensi
}

\begin{abstract}
Cryptogams are a group of lower plants that reproduce by spores without seed production. The fern (Pteridophyta) is a division of cryptogams that has a reasonably wide distribution pattern and is commonly found around the area of UIN Sumatera Utara. This study aims to identify ferns in UIN Sumatera Utara, which are expected to be helpful as a contextual learning development of Cryptogamic Botany. The method used in this research was exploratory and descriptive survey methods, by collecting plant data and observing the morphology and description of these plants. The samples were collected in fresh form and identified in the Laboratory of Biology Education UIN Sumatera Utara. Plant identification used data collection procedures for plant morphological characteristics and identification keys from Plant Taxonomy's book. The results showed two classes of ferns, namely Filicinae and Lycopodiinae, consisting of one order, one family, five sub-families, and six species for Filicinae; one order, one family, and one species for Lycopodiinae found in UIN Sumatera Utara.
\end{abstract}

Keywords: Identification, Pteridophyta, Fern, Botany, Plant Morphology

\begin{abstract}
Abstrak
Cryptogamae merupakan kelompok tumbuhan tingkat rendah yang berkembang biak dengan spora, tanpa adanya biji. Tumbuhan paku (Pteridophyta) merupakan salah satu divisi tumbuhan cryptogamae yang memiliki pola penyebaran yang cukup luas dan lazim ditemui di kawasan UIN Sumatera Utara. Penelitian ini bertujuan untuk mengidentifikasi tumbuhan paku yang terdapat di UIN Sumatera Utara yang diharapkan dapat bermanfaat sebagai pengembangan dalam pembelajaran kontekstual Botani Cryptogamae. Metode yang digunakan dalam penelitian ini ialah metode survey eksploratif dan deskriptif, dengan melakukan pendataan tumbuhan serta mengamati morfologi dan deskripsi tumbuhan tersebut. Sampel dikoleksi dalam bentuk segar dan diidentifikasi di laboratorium Tadris Biologi UIN Sumatera Utara. Identifikasi tumbuhan menggunakan prosedur pendataan ciri morfologi tumbuhan dan kunci identifikasi yang bersumber dari buku Taksonomi Tumbuhan. Hasil penelitian menunjukkan bahwa terdapat 2 kelas tumbuhan paku yakni kelas Filicinae dan Lycopodiinae, yang terdiri atas 1 ordo, 1 famili, 5 sub famili dan 6 spesies untuk Filicinae serta 1 ordo, 1 famili, dan 1 spesies untuk Lycopodiinae yang ditemukan di UIN Sumatera Utara.
\end{abstract}

Kata Kunci: Identifikasi, Pteridophyta, Tumbuhan Paku, Botani, Morfologi Tumbuhan

Diterima: 12 Februari 2020, disetujui: 7 Mei 2020

\section{Pendahuluan}

$\begin{array}{ccc}\text { Tumbuhan } & \text { paku } & \text { (Pteridophyta) } \\ \text { merupakan salah satu divisi tumbuhan }\end{array}$

Cryptogamae yang tiap spesiesnya telah jelas mempunyai kormus karena memiliki akar, batang, dan daun sejati serta memiliki berkas pembuluh angkut yaitu xilem dan floem (Ulfa, 
2017). Tumbuhan ini hidup di habitat yang lembab (higrofit), berbagai tempat di air (hidrofit), dan menempel (epifit) pada permukaan batu, tanah, dan pohon (Ulfa, 2017). Akan tetapi, jenis tumbuhan paku yang ada saat ini sebagian besar bersifat higrofit. Tumbuhan ini lebih menyukai tempat-tempat yang memiliki kelembaban yang tinggi. Tumbuhan paku paling besar dapat mencapai tinggi beberapa meter, seperti yang terdapat pada marga Cyathea dan Alsophila (Tjitrosoepomo, 2011).

Tumbuhan paku mengalami pergiliran keturunan (gametogenesis), yang masa reproduksinya dapat dibedakan atas fase gametofit dan sporofit yang saling independen (Nurcahyati, 2016). Fase gametofit pada tumbuhan paku memiliki usia yang relatif pendek jika dibandingkan dengan fase sporofit. Struktur gametofit ini berupa protalium dengan tipe perkembangan yang dapat dibedakan menjadi tipe gleichnia, christiopteris, cyathea, hymenophyllum, trichomanes, dan mecodium (Nurcahyati, 2016). Umumnya, protalium ini berbentuk jantung, berwarna hijau, dan melekat pada substrat dengan rizoid dan terdapat sisi anteridium dan arkegonium. Sedangkan, pada fase sporofit memungkinkan zigot tumbuh menjadi individu diploid dengan adanya mekanisme perkembangan haustorium yang memisahkan sel-sel calon akar, batang, dan daun (Tjitrosoepomo, 2011).

Tumbuhan paku dapat tersebar dengan mudah, sehingga membentuk keanekaragaman yang dapat diidentifikasi berdasarkan morfologi dan anatominya. Keanekaragaman yang dimaksud adalah kekayaan spesies tumbuhan paku yang dapat ditemukan pada suatu daerah yang ditentukan oleh perkembangbiakannya (Saputro \& Sri, 2020). Perkembangbiakan tumbuhan paku dipengaruhi oleh faktor abiotik dan biotik. Faktor abiotik meliputi temperatur, kelembaban, intensitas cahaya, lokasi geospasial dan ketinggian lokasi. Sementara itu, faktor biotik berhubungan dengan karakteristik spora yang dimiliki oleh tumbuhan paku tersebut (Janna et al, 2020). Identifikasi tumbuhan paku (Pteridophyta) di Sumatera Utara telah dilakukan oleh peneliti sebelumnya seperti penelitian yang melaporkan terdapat 17 jenis tumbuhan paku yang tergolong ke dalam 2 divisi, 2 kelas dan 12 famili yang ditemukan di
Taman Nasional Batang Gadis Kabupaten Mandailing Natal (Marpaung, 2019) dan terdapat 11 spesies tumbuhan paku yang ditemukan di ruang terbuka hijau kampus Universitas Negeri Medan (Sinaga \& Mauliadi, 2019).

UIN Sumatera Utara merupakan salah satu kampus yang memiliki keanekaragaman tumbuhan paku yang cukup banyak, khususnya di area kampus II. Namun, keberadaan tumbuhan tersebut belum diidentifikasi. Oleh karena itu, penelitian ini bertujuan untuk mengidentifikasi tumbuhan paku di UIN Sumatera Utara dan diharapkan dapat menjadi referensi tambahan untuk mempelajari tumbuhan tingkat rendah (Cryptogamae), khususnya pada divisi Pteridophyta. Penelitian ini juga diharapkan dapat menelisik keanekaragaman tumbuhan paku yang terdapat di UIN Sumatera Utara dan sebagai rujukan terhadap pengembangan dan pelestarian tumbuhan yang bermuatan etnobotani khususnya pada divisi tumbuhan tingkat rendah.

\section{Metode Penelitian}

Penelitian ini dilakukan di kampus II UIN Sumatera Utara pada bulan Oktober 2020. Alat dan bahan yang digunakan dalam penelitian ini yaitu: alat tulis dan tabel pengamatan, kamera digital, buku panduan yang relevan, dan buku kunci determinasi tumbuhan tingkat rendah pada divisi pteridophyta. Sampel pada penelitian ini adalah tumbuhan paku yang terdapat di kawasan kampus II UIN Sumatera Utara. Pengambilan data menggunakan metode eksplorasi atau metode jelajah secara langsung. Identifikasi tumbuhan dilakukan dengan cara pengamatan karakter morfologi tumbuhan meliputi daun (warna daun, panjang daun, dan lebar daun) dan batang (bentuk batang dan ciri khas morfologinya). Spesimen dideterminasi dengan referensi rujukan menggunakan buku referensi Tjitrosoepomo (2011). Analisis data dilakukan secara deskriptif kualitatif, dengan pengambilan sampel, didokumentasikan, dan diidentifikasi (Ulfa, 2017). 


\section{Hasil dan Pembahasan}

Sejumlah spesies hasil pengamatan identifikasi tumbuhan paku di UIN Sumatera Utara ditunjukkan pada Gambar 1. Berdasarkan pengamatan tumbuhan paku pada divisi Pteridophyta di UIN Sumatera Utara, maka diperoleh sistematika taksonomi tumbuhan yang ditunjukkan pada Tabel 1 .

Menurut hasil pengamatan di atas, maka dapat diketahui bahwa terdapat 2 kelas tumbuhan paku pada divisi Pteridophyta yang ditemukan di UIN Sumatera Utara. Pada kelas
Filicinae hanya ditemukan 1 ordo tumbuhan paku yaitu Leptosporangiales yang hanya memiliki 1 famili tumbuhan paku yaitu Polypodiaceae. Famili tumbuhan tersebut dibagi ke dalam 5 sub famili tumbuhan yang berbeda dimana masing-masing sub famili memiliki 1 spesies tumbuhan, kecuali pada sub famili Davallieae yang memiliki 2 spesies tumbuhan. Sedangkan, pada kelas Lycopodiinae hanya ditemukan 1 ordo tumbuhan yang hanya mempunyai 1 famili dan 1 spesies.
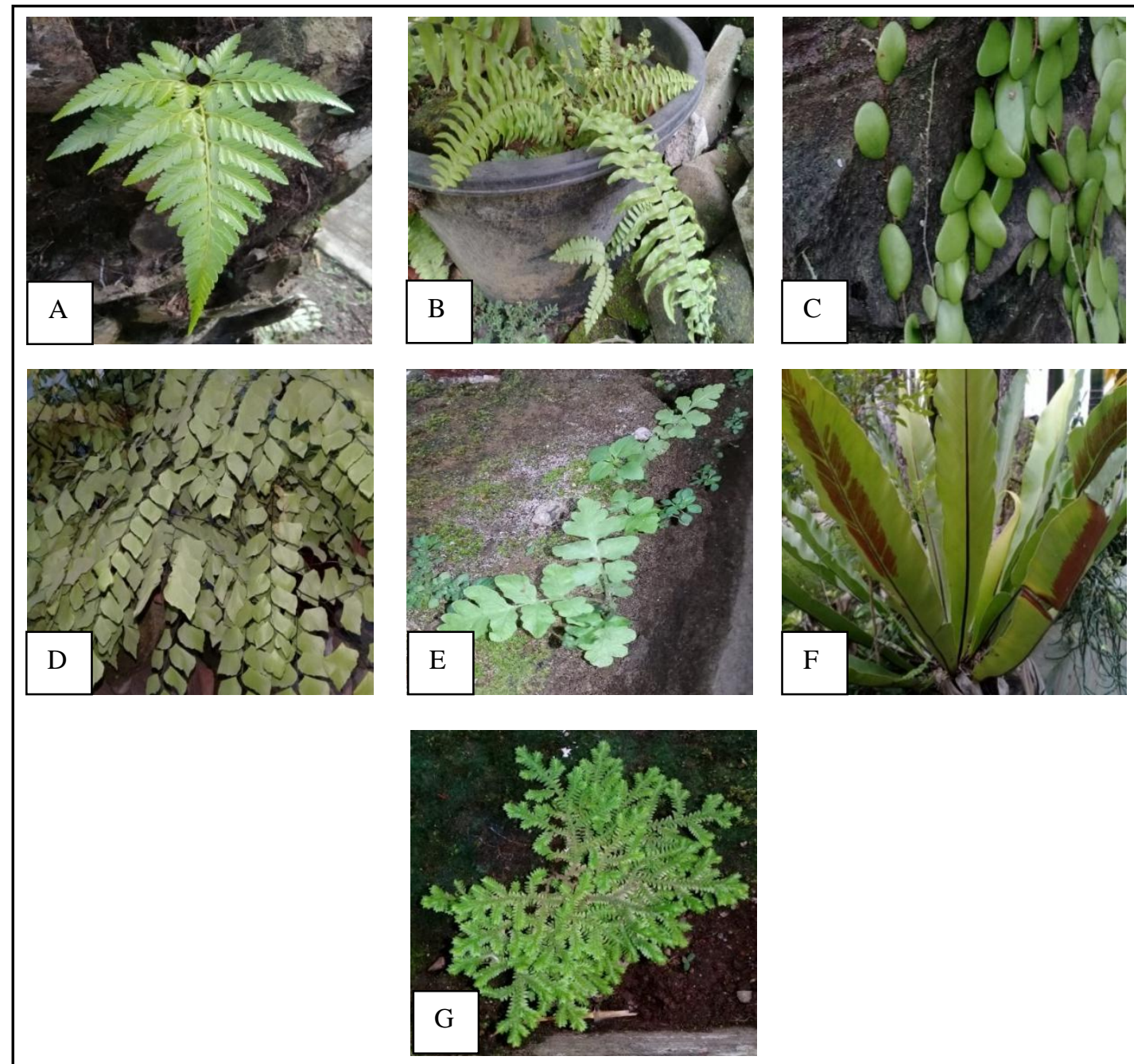

Gambar 1. Keanekaragaman Tumbuhan Paku yang Ditemukan di UIN Sumatera Utara: (A) Davallia trichomanoides Linn Pr., (B) Nephrolepis exaltata(Sw) Schott., (C) Drymoglossum piloselloides Linn Pr., (D) Adiantum cuneatum Langs \& Fisch, (E) Polypodium vulgare, (F) Asplenium nidus Linn,, (G) Selaginella sp. 
Tabel 1. Keanekaragaman Tumbuhan Paku (Pteridophyta) di UIN Sumatera Utara (Klasifikasi Tumbuhan Berdasarkan Tjitrosoepomo, 2011)

\begin{tabular}{|c|c|c|c|c|c|}
\hline Kelas & Ordo & Famili & Sub Famili & Genus & Spesies \\
\hline \multirow[t]{6}{*}{ Filicinae } & \multirow[t]{6}{*}{ Leptosporangiales } & \multirow[t]{6}{*}{ Polypodiaceae } & \multirow[t]{2}{*}{ Davallieae } & Davallia & $\begin{array}{l}\text { Davallia } \\
\text { trichomanoides } \\
\text { Linn Pr. }\end{array}$ \\
\hline & & & & Nephrolepis & $\begin{array}{l}\text { Nephrolepis } \\
\text { exaltata(Sw) } \\
\text { Schott. }\end{array}$ \\
\hline & & & Vittarieae & Drymoglossum & $\begin{array}{l}\text { Drymoglossum } \\
\text { piloselloides } \\
\text { Linn Pr. }\end{array}$ \\
\hline & & & Pterideae & Adiantum & $\begin{array}{l}\text { Adiantum } \\
\text { cuneatum Langs } \\
\text { \& Fisch }\end{array}$ \\
\hline & & & Polypodieae & Polypodium & $\begin{array}{l}\text { Polypodium } \\
\text { vulgare }\end{array}$ \\
\hline & & & Asplenieae & Asplenium & $\begin{array}{l}\text { Asplenium nidus } \\
\text { Linn. }\end{array}$ \\
\hline Lycopodiinae & Selaginellales & Selaginellaceae & - & Selaginella & Selaginella sp. \\
\hline
\end{tabular}

Tjitrosoepomo (2011) menjelaskan bahwa kelas Filicinae merupakan salah satu kelas divisi Pteridophyta yang lazim disebut sebagai tumbuhan paku sebenarnya. Hal ini sesuai menurut Ulfa (2017) yang menyatakan bahwa kelas Filicinae tergolong ke dalam tumbuhan paku sebenarnya karena tumbuhan ini telah memiliki akar, batang, dan daun sejati. Ditinjau dari ekologisnya, tumbuhan paku dari kelas Filicinae termasuk higrofit dan epifit. Hal ini sesuai berdasarkan fakta pengamatan yang menunjukkan bahwa spesies tumbuhan tersebut banyak ditemukan di daerah lembab seperti di bawah naungan pohon, di tempat yang basah, dan daerah yang tidak terpapar sinar matahari terlalu intensif serta menempel pada permukaan tanah (Nephrolepis exaltata, Adiantum cuneatum, Asplenium nidus), batu (Polypodium vulgare), dan batang (Davallia trichomanoides, Drymoglossum piloselloides).

$$
\text { Tjitrosoepomo (2011) juga }
$$

menambahkan seluruh spesies Filicinae memiliki daun besar (makrofil), bertangkai, dan bertulang daun. Daun muda menggulung pada saat masih muda dan ketika dewasa akan memiliki banyak sporangium. Hal ini sesuai menurut hasil pengamatan tumbuhan tersebut yang mengindikasikan adanya daun muda yang tergulung dan beberapa daun dewasa yang dilingkupi oleh butiran sporangium. Daun bersporangium ini hanya dimiliki oleh tumbuhan paku yang memiliki daun sporofil. Sedangkan, daun yang tidak bersporangium dimiliki oleh tumbuhan paku yang mempunyai daun tropofil. Hal ini sesuai menurut Ulfa (2017) yang menyatakan bahwa daun tumbuhan paku dapat dibagi menjadi dua jenis yaitu daun berspora (sporofil) dan tidak berspora (tropofil). Hal yang sama juga dipertegas oleh A'tourrohman et al. (2020) yang menjelaskan bahwa sporofil memiliki bentuk lebih panjang dari tropofil dan memiliki sporangium, sedangkan tropofil lebih kecil dengan bentuk bulat.

Berdasarkan fakta di lapangan, Davallia trichomanoides banyak ditemukan pada batang pohon kelapa sawit dengan daun berwarna hijau cerah. Meliza et al (2019) menyatakan bahwa Davallia trichomanoides dapat tumbuh secara epifit pada batang pohon dan secara epilitik pada bebatuan. Spesies ini banyak ditemukan di tempat lembab dan terbuka. Davallia trichomanoides memiliki helaian daun menyirip ganda tiga, vena berlobus tunggal atau menggarpu dan tidak mencapai tepi daun. Nasution et al. (2018) menegaskan bahwa Davallia trichomanoides dapat dimanfaatkan sebagai tanaman hias karena memiliki bentuk yang indah dan berkhasiat sebagai tanaman obat.

Nephrolepis exaltata merupakan spesies tumbuhan paku yang ditemukan di lokasi pengamatan dengan ciri morfologi berupa akar serabut, daun berwarna hijau berbentuk helaian daun lanset, dan batang berwarna coklat. Hal ini senada menurut Diliarosta et al. (2020) yang mengungkapkan bahwa Nephrolepis exaltata termasuk ke dalam spesies tumbuhan 
paku yang mudah dikenali karena memiliki ciri morfologi yang khas berupa bentuk daun pelepah pedang yang memanjang, rimpang tipis menyerupai akar serabut, dan anak daun menyirip bersusun tunggal. Menurut Merlina \& Ngadiani (2020), tumbuhan ini berkhasiat sebagai obat kulit karena memiliki kandungan metabolit sekunder berupa flavonoid, saponin, kardenolin, dan tanin. Kandungan senyawa tersebut berfungsi mendenaturasi protein sel jamur dan bersifat lipofilik, sehingga efektif untuk menghambat pertumbuhan jamur, khususnya Candida albicans yang menyebabkan penyakit panu.

Menurut Prastyo (2015), Drymoglossum piloselloides memiliki ciri khas berupa daun berwarna hijau dan berbentuk bulat atau oval yang tumbuh melekat pada batang utama. Tumbuhan ini banyak tumbuh secara epifit di batang-batang pohon. Hal ini sesuai dengan fakta di lapangan dimana Drymoglossum piloselloides banyak ditemukan menjalar pada batang pohon. Akarnya melekat kuat pada batang yang ditumpangi dengan daun berbentuk seperti sisik naga berwarna hijau. Selain itu, Sahid et al. (2013) menambahkan bahwa Drymoglossum piloselloides dapat dimanfaatkan sebagai tanaman obat karena mengandung senyawa flavonoid, tanin, steroid atau triterpenoid, minyak atsiri dan glikosida yang berpotensi sebagai anti kanker. Ekstraksi daun Drymoglossum piloselloides mampu melarutkan unsur bioaktif termasuk sel leukimia dalam tubuh manusia.

Hasil pengamatan menunjukkan bahwa Adiantum cuneatum memiliki daun majemuk berwarna hijau, batang berupa rimpang, dan akar serabut. Hal yang sama juga diungkapkan oleh Ayatusa'adah \& Nor (2017) bahwa Adiantum cuneatum memiliki daun berwarna hijau muda, tepi daun rata dan ujung daun tumpul membulat. Tumbuhan ini tergolong tumbuhan epifit atau dapat juga tumbuh pada permukaan tanah yang lembab. Wardiah et al. (2019) menambahkan Adiantum cuneatum mengandung flavonoid dan lazim diolah oleh masyarakat dalam bentuk teh untuk mengobati batuk dan hidung tersumbat. Selain itu, kandungan fosfor yang dimiliki tumbuhan ini juga efektif untuk memelihara kesehatan tulang dan gigi. Kemampuannya dalam mereduksi senyawa berbahaya seperti arsenik dari tanah menyebabkan tumbuhan ini baik digunakan sebagai fitoremediator untuk menjaga kualitas lingkungan.

Polypodium vulgare yang ditemukan di lokasi pengamatan memiliki daun tunggal berwarna hijau muda berbentuk lanset dengan ujungnya menyirip dan tepi rata. Sorus atau spora berada di ujung daun dengan bentuk memanjang berwarna coklat kehitaman. Spesies ini memiliki sistem perakaran serabut dan banyak ditemukan menempel pada bebatuan yang lembab. Sofiyanti \& Mayta (2018) menyatakan bahwa Polypodium vulgare tergolong ke dalam famili Polypodiaceae yang memiliki daun berwarna hijau dan bersifat epifit pada batang pepohonan atau bebatuan. Ambarwati et (2019) menegaskan Polypodium vulgare berperan penting terhadap aspek ekologi, dimana tumbuhan ini berpengaruh positif dalam Agrofestri untuk menyediakan cadangan karbon lingkungan yang berkualitas.

Asplenium nidus yang ditemukan bercirikan adanya helaian daun yang tersusun membentuk roset dan menyerupai sarang. Bentuk ujung daun meruncing atau membulat dengan tepi daun rata dan memiliki tekstur permukaan daun berombak atau mengkilat. Hal yang sama juga diungkapkan oleh Nurchayati (2016) bahwa Asplenium nidus memiliki daun berwarna hijau dengan susunan daun membentuk roset melingkar. Bagian bawah daun berwarna lebih pucat dibandingkan bagian atasnya. Urat daun menyirip tunggal dengan tulang daun menonjol pada bagian atasnya. Spesies ini memiliki spora berbentuk ellipse (elipticus) dan berwarna kuning kecoklatan serta memiliki ornamen seperti jaring (retiformis foveatus). Pranita et al. (2017) juga menambahkan bahwa Asplenium nidus memiliki ciri khas berupa hampir semua sori tersusun linear dan spora berbentuk ellipse. Selain itu, Wahyuningsih et al (2019) menyatakan Asplenium nidus banyak dimanfaatkan sebagai tanaman hias karena memiliki bentuk yang indah dan nilai estetika yang tinggi.

Berdasarkan pengamatan terhadap tumbuhan paku pada kelas Lycopodiinae dapat dipahami bahwa Selaginella sp. memiliki batang dan akar bercabang-cabang menggarpu. Daunnya kecil (mikrofil) dan tersusun seperti "lidah-lidah" (ligula). Daun tersebut tersusun rapat menurut garis spiral. Hanya ditemukan sedikit saja daun yang bersifat sporofil yang terkumpul dalam suatu rangkaian pada ujung 
batang. Menurut Tjitrosoepomo (2011), Selaginella sp. memiliki cabang yang menggarpu anisotom dan pada batangnya terdapat daun-daun kecil yang tersusun dalam garis spiral membentuk 4 baris. Pada bagian bawah sisi atas daun terdapat suatu sisik yang dinamakan ligula. Bagian ini merupakan alat penghisap air yang seringkali berhubungan dengan pembuluh pengangkut melalui perantara trakeida. Hutasuhut \& Husnarika (2019) juga menegaskan Selaginella sp. berhabitat di tempat terrestrial dengan ental menyirip tunggal dan anak daun berbentuk lonjong. Percabangan secara dikotom dan sori muncul pada anak daun daun dalam indusia yang berbentuk seperti tabung dalam tangkai yang menjulur.

Secara keseluruhan, tumbuhan paku yang ditemukan di kawasan UIN Sumatera Utara mengalami pertumbuhan dan perkembangan yang baik, yakni ditandai dengan suburnya kehidupan tumbuhan, warna hijau cerah pada batang dan daun serta bentuk morfologi spora yang baik. Hal ini mengindikasikan bahwa UIN Sumatera Utara merupakan tempat yang cocok bagi tumbuh kembang tumbuhan paku karena memiliki faktor lingkungan yang sesuai bagi tumbuhan tersebut. Idealnya, tumbuhan paku dapat tumbuh dan berkembang dengan baik di lokasi dengan suhu udara berkisar antara $21-27^{\circ} \mathrm{C}$, kelembaban berkisar antara 60-90\%, dan $\mathrm{pH}$ dengan nilai berkisar 5,5-8,0 (Saputro \& Sri, 2020). Hal yang sama juga dipertegas oleh Janna et al. (2020) yang menyatakan bahwa pertumbuhan dan perkembangan tumbuhan paku sangat ditentukan oleh faktor abiotik yang berada pada ambang batas normal dengan karakteristik kelembaban tanah 60-90\%, suhu lingkungan $27^{\circ} \mathrm{C}-28^{\circ} \mathrm{C}$, dan $\mathrm{pH}$ substrat berkisar $7-8$.

Selain faktor abiotik, faktor lain yang mempengaruhi penyebaran tumbuhan paku ialah dispersal spora yang merupakan bagian faktor biotik tumbuhan tersebut. Menurut hasil pengamatan di lokasi penelitian dapat diketahui bahwa Polypodiaceae memiliki spesies paling banyak ditemukan dibandingkan Selaginellaceae. Kondisi ini mengindikasikan bahwa Polypodiaceae yang ditemukan di UIN Sumatera Utara memiliki dispersal spora yang lebih signifikan. Hal ini sesuai menurut Saputro \& Sri (2020) yang menerangkan bahwa dispersal spora sangat mempengaruhi kelimpahan tumbuhan paku di suatu lingkungan. Apabila kelimpahannya tinggi, maka dapat dipastikan dispersal spora tumbuhan paku tersebut juga tinggi. Windadri (2010) menambahkan kelimpahan tumbuhan tingkat rendah ditentukan oleh spora karena spora mudah diterpa angin dan hinggap di tempat yang sesuai untuk tumbuh menjadi individu baru. Dengan demikian, dispersal spora pada tumbuhan paku menjadi kunci utama banyak sedikitnya tumbuhan paku yang akan tumbuh.

Keragaman spesies tumbuhan paku yang ditemukan di UIN Sumatera Utara berpotensi dan memberikan manfaat terhadap berbagai aspek kehidupan, seperti bidang ekonomi, estetika, dan sosial. Khususnya, ketersediaan sumber belajar pada mata kuliah Botani Cryptogamae divisi Pteridophyta. Dengan adanya keberagaman tumbuhan paku tersebut mahasiswa dapat mengenali dan mengidentifikasi spesies tumbuhan paku berdasarkan ciri morfologinya. Kegiatan ini akan mendukung pelaksanaan praktikum pada materi identifikasi tumbuhan tingkat rendah, dimana mahasiswa dapat mengambil spesimen tumbuhan dari lingkungan sekitar dan mengamatinya.

\section{Simpulan}

Tumbuhan paku (Pteridophyta) yang ditemukan di UIN Sumatera Utara yaitu Filicinae dan Lycopodiinae. Kelas Filicinae lebih dominan ditemukan yakni terdapat 1 ordo dan 1 famili dengan 5 sub famili yang berbeda. Total spesies yang ditemukan dari kelas Filicinae ialah 6 spesies. Sementara itu, kelas Lycopodiinae paling sedikit ditemukan di area pengamatan yaitu hanya terdapat 1 ordo, 1 famili, dan 1 spesies. Keanekaragaman spesies tumbuhan paku tersebut berpotensi untuk dimanfaatkan sebagai penyediaan spesimen tumbuhan paku untuk mempelajari karakteristik dan ciri morfologinya, tumbuhan obat, serta pengembangan tumbuhan yang memiliki nilai ekonomi dan estetika.

Penelitian lanjutan dapat dilakukan untuk mengkaji secara spesifik usaha budidaya tumbuhan paku disertai analisis faktor pendukung keberhasilan usaha tersebut berdasarkan kondisi lingkungan di UIN Sumatera Utara. Hal ini dilandasi oleh potensi 
kebermanfaatan spesies tumbuhan paku yang ada di UIN Sumatera Utara demi terwujudnya kampus berbasis etnobotani dan pelestarian alam menggunakan potensi lokal.

\section{Daftar Pustaka}

Ambarwati, A., Duryat, \& Wahyu H. (2019). INP Vegetasi dan Karbon Tersimpan pada HKm Bina Wana Kecamatan Kebun Tebu Kabupaten Lampung Barat. Jurnal Hutan Tropis. 7(2), 112-119.

Ariyanti, M., S. Yahya, K. Murtilaksono, Suwarto, \& H. H. Siregar. (2016). Pengaruh Tanaman Penutup Tanah Nephrolepis biserrata dan Teras Gulud Terhadap Aliran Permukaan dan Pertumbuhan Kelapa Sawit (Elaeis guineensis.Jacq.). Jurnal Kultivasi. 15(2), 121-127.

A’tourrohman, M., Muhammad A. S., Riza E. N., Sinta D. R., Siti F., Dian N. M. \& Lianah. (2020). Keanekaragaman Jenis Pakupakuan (Pteridophyta) dan Kajian Potensi Pemanfaatannya di Cagar Alam Ulolanang Kecubung. Jurnal Bioeduscience. 4(1), 7381.

Ayatussa'adah \& Nor A. D. (2017). Inventarisasi Tumbuhan Paku (Pteridophyta) di Kawasan Kampus IAIN Palangka Raya sebagai Alternatif Media Pembelajaran Materi Klasifikasi Tumbuhan. Jurnal Edusains, 5(2), 50-61.

Darma, I D. P. Wenni S. L., Arief P. \& Rajif I. (2018). Paku Epifit dan Pohon Inangnya di Bukit Pengelengan, Tapak dan Lesung, Bedugul, Bali. Jurnal Penelitian Hutan dan Konservasi Alam. 15(1), 41-50.

Diliarosta, S., Rehani, R. \& Dewi I. (2020). Diversity of Pteridophyta in Lubuak Mato Kuciang Padang Panjang, Sumatera Barat. Pharmacognosy Journal, 12(1), 180-185.

Hutasuhut, M. A. \& Husnarika F. (2019). Keanekaragaman Paku-pakuan Terestrial di Kawasan Taman Wisata Alam SicikeCike. Jurnal Biolokus: Jurnal Penelitian Pendidikan Biologi dan Biologi. 2(1), 146157.

Janna, M., Reny, D.R. \& Sepriyaningsih. (2020). Keanekaragaman Jenis Tumbuhan Pteridophyta (Paku-Pakuan) Di Kawasan Curug Panjang Desa Durian Remuk Kabupaten Musi Rawas. Jurnal Biologi dan Pembelajarannya. 7(1), 19-22.
Marpaung, D. R. A. K. (2019). Inventarisasi Tumbuhan Paku (Pteridophyta) di Sopotinjak Taman Nasional Batang Gadis (TNBG) Kabupaten Mandailing Natal. Jurnal Penelitian dan Pembelajaran MIPA. 4(2), 79-134.

Meliza, R., Tatik C. \& Sulistijorini. (2019). Morfologi Spora dan Perkembangan Gametofit Davallia denticulate dan Davallia trichomanoides. Jurnal Bioteknologi dan Biosains Indonesia. 6(1), 1-10.

Merlina, D. M. \& Ngadiani. (2020). Uji Efektivitas Ekstrak Paku Pedang (Nephrolepis exaltata) terhadap Pertumbuhan Jamur Candida albicans. Stigma: Jurnal Matematika dan Ilmu Pengetahuan Alam Unipa. 13(1), 33-38.

Nasution, J., Jamilah N. \& Emmy H. K. (2018). Inventarisasi Tumbuhan Paku di Kampus I Universitas Medan Area. Klorofil: Jurnal Ilmu Biologi dan Terapan. 1(2), 105-110.

Nurcahyati, N. (2016). Identifikasi Profil Karakteristik Morfologi Spora Dan Prothalium Tumbuhan Paku Familia Polypodiaceae. Jurnal Bioedukasi. 14(2), 25-30.

Oroh, S. B., Febby, E. F. K., Johanis P. \& Dingse P. (2015). Uji Daya Hambat Ekstrak Metanol Selaginella delicatula dan Diplazium dilatatum terhadap Bakteri Staphylococcus aureus dan Escherichia coli. Jurnal Ilmiah Sains. 15(1), 52-58.

Pranita, H. S., Susriyati M. \& Murni S. S. (2017). Karakteristik Spora Tumbuhan Paku Asplenium Kawasan Hutan Raya S. Soerjo. Jurnal Pendidikan, 2(4), 454-458.

Prastyo, W. R., Suwasono H. \& Agung Nugroho. (2015). Identifikasi Tumbuhan Paku Epifit pada Batang Tanaman Kelapa Sawit (Elaeis Guineensis J.) di Lingkungan Universitas Brawijaya. Jurnal Produksi Tanaman, 3(1), 65-74.

Sahid, A., Dingse P., Parluhutan S. \& Marhaenus J. R. (2013). Uji Sitotoksisitas Ekstrak Metanol Daun Sisik Naga (Drymoglossum piloselloides Presl.) terhadap Sel Leukemia P388. Jurnal MIPA Unsrat. 2(2), 94-99.

Saputro, R. W. \& Sri U. (2020). Keanekaragaman Tumbuhan Paku (Pteridophyta) di Kawasan Candi Gedong Songo Kabupaten Semarang. Jurnal Bioma. 22(1), 53-58. 
Sinaga, J. N. \& Mauliadi. (2019). Identifikasi Tumbuhan Tingkat Tinggi yang Ditemukan di Ruang Terbuka Hijau (RTH) Universitas Negeri Medan (UNIMED). Prosiding Seminar Nasional Peningkatan Mutu Pendidikan. 1(1), 203-206.

Sofiyanti, N. \& Mayta N. I. (2018). Kajian Morfologi dan Mikromorfologi (Sisik serta Trikoma) 4 Jenis Pyrrosia Mirb. (Polypodiaceae) di Provinsi Riau. Jurnal Biologi Tropis, 18(2), 174-181.

Tjitrosoepomo, G. (2011). Taksonomi Tumbuhan: Schizophyta, Thallpophyta, Bryophyta, Pteridophyta. Yogyakarta: Gadjah Mada University Press.

Ulfa, S. W. (2017). Botani Cryptogamae. Medan: Perdana Publishing.
Wahyuningsih, Merti T. \& Sepriyaningsih. (2019). Inventarisasi Tumbuhan Paku (Pteridophyta) di Perkebunan PT Bina Sains Cemerlang Kabupaten Musi Rawas. Jurnal Biosilampari. 2(1), 29-35. DOI: 10.31540/biosilampari.v2i1.815.

Wardiah., Intan S., Hasanuddin, Cut N. \& Dewi A. (2019). Pteridophyta di Kawasan Air Terjun Suhom Kecamatan Lhoong Kabupaten Aceh Besar. Jurnal Biotik. 7(2), 89-95.

Windadri, F. I. (2010). Keanekaragaman Lumut di Kawasan Cagar Alam Dungus Iwul, Jasinga, Jawa Barat. Biota: Jurnal Ilmiah Ilmu-ilmu Hayati. 15(3), 400-406. 